\title{
Nineteenth-Century English Fiction as a Source for Teaching Discourse Presentation Strategies to Spanish EFL Students: A Corpus-Based Approach to Direct Speech Reporting Verbs
}

\author{
Pablo Ruano San Segundo \\ Universidad de Extremadura
}

Received: 25 February 2015 / Accepted: 12 August 2015

ISSN: $1697-7467$

\begin{abstract}
Direct speech has traditionally lacked the attention devoted to indirect speech in EFL teaching in the Spanish curriculum. The verbatim representation of the speech act being reported seems as a taken-for-granted construction which does not need further analysis. Thanks to a corpus-based approach, though, it is possible to retrieve data that prove otherwise. Reporting verbs will be the element under analysis, since they make it possible to demonstrate that the way in which discourse is projected can be highly interpretative. The analysis will consist of a corpus-based study of more than eighty English Victorian novels (c. 16.8 million words). It will be carried out with WordSmith Tools (Scott, 2013), which allows the retrieval of more than 30,000 verbs.

Keywords: corpus-based approach, Victorian fiction, direct speech, teaching, reporting verbs.

RESUMEN: El estilo directo ha carecido tradicionalmente de la atención que sí ha recibido el estilo indirecto en la enseñanza del inglés como lengua extranjera en España. La cita literal del acto de habla que se representa parece hacer innecesaria su enseñanza en contextos de aprendizaje de una lengua. Gracias a un enfoque de corpus, sin embargo, es posible aglutinar el material suficiente para demostrar que esto no es así. Los verbos de habla serán el objeto de estudio de este trabajo, pues servirán para ratificar que la manera en que se proyecta el discurso es decisiva a la hora de percibirlo. El análisis consistirá en un estudio basado en corpus de más de ochenta novelas victorianas. Se realizará con WordSmith Tools (Scott, 2013), que permite rescatar más de treinta mil verbos de habla para su posterior estudio.

Palabras clave: estudio de corpus, novela victoriana, estilo directo, enseñanza, verbos de habla.
\end{abstract}

\section{INTRODUCTION}

There is no gainsaying the fact that in teaching discourse presentation strategies in English as a foreign language (EFL) in Spain, indirect speech -the so-called reported speechhas traditionally received much more attention than any other strategy ${ }^{1}$. Admittedly, indirect

${ }^{1}$ This is best reflected in the new Organic Law on education (Ley Orgánica para la Mejora de la Calidad Educativa, LOMCE), whose last changes have been recently published in the Official State Bulletin (BOE) (January 3, 2015) (available in: http://www.boe.es/boe/dias/2015/01/03/pdfs/BOE-A-2015-37.pdf; accessed February 24, 2015). 
speech poses a great challenge for students due to the alterations that must be made in the sentence being reported (personal pronouns, adjuncts of time, tense switch, etc.) ${ }^{2}$. Be that as it may, however, none of the remaining four strategies are even touched in textbooks, let alone a systematic analysis of their structural patterns, usage, etc. carried out. Analyses are, more often than not, totally neglected. This is especially true of direct speech. Whether because of its simple structure ${ }^{3}$ or maybe due to a question of prioritising what to teach, the truth is that there exists a traditional lack of attention when teaching the discourse presentation strategy par excellence.

It is in consonance with these perceptions that this research has been carried out. I will try to demonstrate that direct speech is a strategy worthy of being taught not only because it entails a total control of the words glossed -despite the word for word reproduction, which makes many students think otherwise-, but also because of the wide range of possibilities it offers when it comes to adopting different stances towards someone else's words. To do so, I will focus on reporting verbs, an element most conspicuous and yet apparently so far overlooked in EFL teaching too. As will be demonstrated here, verbs of saying may play a role that goes well beyond the linguistic function they play by their very nature. Such role is, to say the least, worth dealing with in the context of EFL teaching, both because of the implications that different choices may entail and because of the vast catalogue of verbs that can be learned.

The analysis will consist of a corpus-based study of more than eighty English novels by eight different nineteenth-century Victorian authors. It will be carried out with the help of WordSmith Tools version 6 (C) (Scott, 2013), which allows the retrieval of more than 30,000 verbs. This amount of data will constitute a fertile soil both to challenge the implications entailed by the use of certain verbs and to compile a catalogue of reporting verbs available to anyone interested in such element. It will furthermore help to integrate literature in the curriculum, a still unresolved matter in EFL teaching in Spain.

\section{Direct SPEECH AND REPORTING VERBS}

Discourse presentation strategies are usually regarded as an axis from NRSA (narrative report of speech acts) to FDS (free direct speech), including IS (indirect speech), FIS (free indirect speech) and DS (direct speech) (cf. Semino and Short, 2004: 11). These categories are "associated with varying degrees of faithfulness to an original" (Leech and Short, 2007: 302), FDS being the closest imitation to reality and NRSA being the most detached. Nevertheless, whatever the option chosen to report discourse, they are all powerful strategies used to convey different meanings, which "may affect the ways utterances are received and interpreted by readers" (Caldas Coulthard, 1988: 6-7). Direct speech, of course, is no exception. It is

\footnotetext{
Indirect speech is, in fact, the only strategy discussed in the curriculum, with different aspects being dealt with at different stages. Thus, in $4^{\circ}$ ESO it is referred to as "estilo indirecto (reported information, offers, suggestions and commands)"; in $1^{\circ}$ Bachillerato as "estilo indirecto (reported information, offers, suggestions, promises, commands, wishes)"; and in $2^{\circ}$ Bachillerato as "estilo indirecto (reported information, offers, suggestions, promises, commands, wishes, warnings)". Nevertheless, there is no mention to any other strategy whatsoever throughout the curriculum.

${ }^{2}$ For instance, "“I will leave tomorrow"" turns into "He said he would leave the following day".

3 ““'I will leave tomorrow"” can simply become "He said: "I will leave tomorrow"”.
} 
true, though, that "as we move along the cline of speech presentation from the more bound to the more free end, his [the reporter's] interference seems to become less and less noticeable" (Leech and Short, 2007: 259) (my emphasis) ${ }^{4}$. But this is, as Leech and Short claim, just appearance, since tellers are always "in charge of selecting, ordering and organizing the sequence in which events will be recounted. There is always a choice and a construction" (Caldas-Coulthard, 1988: 23). Therefore, "it is misleading to say that in DS the narrator is not in control" (ibid.: 129). Let us see Caldas-Coulthard's (1987: 149) following examples:

(1) "How are you?" John said. "Very well" Mary said.

(2) "How are you?" John asked. "Very well" Mary answered.

(3) "How are you?" John grunted. "Very well" Mary conceded.

(4) "How are you?" John inquired in an affectionate tone. "Very well" Mary replied vaguely.

Indeed, primary discourse can be "intrusive and highly interpretative" (Caldas-Coulthard, 1988: 138.) despite the verbatim representation of the original utterance. As can be seen in examples (1) to (4), the reported averral can be manipulated to a greater or lesser extent through the use of reporting verbs. Nothing of the like, however, is ever mentioned in Spanish EFL textbooks. On the contrary, when teaching discourse presentation strategies, attention is mainly placed on indirect speech and efforts are devoted to ensuring students' understanding of the changes to be made with respect to the original utterance. This lack of attention results in a gap which affects students' ability to see beyond the true but limited understanding of direct speech as a mere word for word reproduction of the original utterance.

Besides, due to this neglect, it is not surprising that artificially-created examples are but simple monotonous choices which pose no challenge from the learner's point of view. This is best reflected in simplified literary texts designed for EFL students at different stages of development. Even with upper-intermediate and advanced texts, where students are supposed to be able to deal with complex samples of language, direct speech instances still rest on mostly neutral verbs. To take but one example, let us have a look at the following excerpt from Penguin Reader's Charles Dickens' A Tale of Two Cities (Dickens, 2000: 41):

(5) After a long silence, the first Jacques said, "Good, you have acted and spoken truthfully. Will you wait for us a little, outside the door?"

"Of course," said the mender of roads. Defarge got up and went with him to the top of the stairs, and then returned.

"What do you say, Jacques?" said Number One. "Shall we put them on the list?"

"On the list for destruction - yes," said Defarge.

"The castle and all the family of Evrémonde?" inquired the first.

"The castle and all the family," replied Defarge.

The verbs used are simple, neutral and demand no effort on the part of the reader.

\footnotetext{
${ }^{4}$ That is why direct speech "is supposed to bring with it a further faithfulness claim as it reports verbatim the speech act value, the grammatical structure and the words of the utterance as well as its propositional content" (Busse, 2010: 27-28).
} 
They barely play a guiding function through the dialogue. These choices have very little to do with the real text ${ }^{5}$ :

(6) After a gloomy silence, the first Jacques said, "Good! You have acted and recounted faithfully. Will you wait for us a little, outside the door?"

"Very willingly," said the mender of roads. Whom Defarge escorted to the top of the stairs, and, leaving seated there, returned.

The three had risen, and their heads were together when he came back to the garret. "How say you, Jacques?" demanded Number One. "To be registered?"

"To be registered, as doomed to destruction," returned Defarge.

"Magnificent!" croaked the man with the craving.

"The chateau, and all the race?" inquired the first.

"The chateau and all the race," returned Defarge. "Extermination."

The hungry man repeated, in a rapturous croak, "Magnificent!" and began gnawing another finger.

As can be seen, Dickens' original choices are much more specific. Thus, apart from common neutral and structuring verbs such as said, returned, inquired or repeated, there is also a character who demands and another who croaks. Beyond the stylistic variation that these choices entail, both demanded and croaked hint at the characters' attitudes ${ }^{6}$. Admittedly, certain nuances are implied in their use which could have not been perceived if the verbs chosen to gloss their words had been said or replied, for instance. Of course, the same level of refinement is not required in a simplified version of the novel for students (no matter what level we are dealing with). However, a systematic substitution of neutral verbs for the original meaningful choices results in a loss of details beyond the linguistic function that verbs play by their very nature. Unfortunately, this is not a one-time thing taking place only in Penguin Reader's Charles Dickens' A Tale of Two Cities, but it is generalisable to the rest of literary simplified versions and direct speech samples in EFL textbooks in general.

Bearing in mind the implications of reporting verbs, one might wonder with salutary common sense, therefore, why direct speech -or discourse presentation strategies in generalare not dealt with in EFL teaching beyond the structural changes taking place in indirect speech. Needless to say, this does not mean that indirect speech should not be taught. Quite on the contrary, and given the implications entailed in different reporting choices, the ideal scenario would be one in which a more comprehensive teaching of discourse presentation strategies were possible. Difficult as this may be, in the particular case of this paper a methodology for the search and retrieval of reporting verbs within direct speech is presented. Thanks to it, it will be possible to retrieve thousands of examples, as shown in section 4 . Some of them will be analysed, which will both demonstrate the importance of reporting verbs in terms of adopting a stance and challenge the teaching of discourse presentation strategies in traditional EFL teaching contexts.

\footnotetext{
${ }^{5}$ Except for examples (1) to (5) and (19) to (22), all examples throughout the paper are from e-texts. Therefore, page numbers are not provided.

${ }^{6}$ For a more detailed analysis on the implications of using croaked, see section 5.
} 


\section{Methodology}

As far as the search for verbs is concerned, a corpus-based methodology has been used. Texts have been processed with the software WordSmith Tools version 6 (C) (Scott, $2013)^{7}$. As already mentioned, they all belong to nineteenth-century Victorian fiction ${ }^{8}$. The corpus consists of eighty-four texts by eight well-known novelists, namely, Charlotte Brontë, Charles Dickens, George Eliot, Elizabeth Gaskell, Thomas Hardy, George Meredith, William M. Thackeray and Anthony Trollope9. The total amount of novels adds up to nearly 16.8 million words. There are between four and fourteen novels per author. This unbalance was necessary to reach such a large amount of text, since not every author was equally prolific.

From a procedural standpoint, direct speech presents some advantages which make the retrieval of verbs possible with a software tool. As Lambert (1981: 31-32) states, "(a)s we enter the period of nineteenth- and twentieth-century novels, we find that an older, Germanic rule still governs the syntax of medially and finally tagged quotation: that is when a sentence begins with the direct object, the verb must follow and the subject then come in the third position." This structural pattern allows a systematic location of reporting verbs, as discussed below ${ }^{10}$. With very few exceptions, novelists always follow the same two patterns when glossing their characters' words under direct speech: placing the projected clause after the projecting clause ${ }^{11}$, with an inversion of the structure subject-verb (example 7), and embedding the projecting clause in the projected clause, also with the aforementioned inversion (example 8$)^{12}$ :

(7) "Miss Jane screamed so loud, ma'am," pleaded Bessie.

(8) "Yaas, to be sure I do," drawled Lord Ingram; "and the poor old stick used to cry out 'Oh you villains childs!' —and then we sermonised her on the presumption of attempting to teach such clever blades as we were, when she was herself so ignorant."

These arrangements share two features that turn out to be crucial for the search of verbs: (i) that authors place no element between the closing inverted comma in the projected clause and the reporting verb and (ii) that reporting verbs are in the past simple tense ${ }^{13}$. Bearing

\footnotetext{
${ }^{7}$ All texts come from Project Gutenberg (www.gutenberg.org). Although their quality can be viewed critically, the amount of data retrieved makes them sufficient for the purposes of this study.

${ }^{8}$ Despite some scholars' reluctance to use literature rather than other sources to analyse language usage, there is no denying that "(1)iterature is a prime example of language in use; no systematic apparatus can claim to describe a language if it does not embrace the literature also" (Sinclair, 2004: 51).

${ }^{9}$ For the list of novels used, see appendix.

${ }^{10}$ In fact, such pattern is still used today, as analysed by Taylor Torsello (2007). Let us take the bestseller Harry Potter and the Philosopher's Stone as an example, in which "the projecting clause almost always comes after the projected clause $(83 \%)$, and only rarely in the middle $(9 \%)$, or before $(8 \%)$. This choice allows Rowling to foreground the dialogue of her characters, leaving the role of the narrator in the background. In these structures we also find Subject-Verb inversion in the projecting clause" (ibid.: 126).

${ }^{11}$ Following the taxonomy of Systemic Functional Grammar, I will for convenience use the concepts of projecting and projected clause (Halliday, 2004: 445) to refer to the narrator's and characters' voices respectively.

${ }^{12}$ Henceforth, and until the end of this section, all the examples shown to illustrate these methodological issues will, for the sake of unity, be taken from Charlotte Brontë's Jane Eyre.

${ }^{13}$ Although at first sight it may seem unnecessary to comment on this, it is worth highlighting the past tense of
} 
in mind that most ways of saying are regular (cf. Wierzbicka, 1987) -with the exception of said and some other examples of little or no importance ${ }^{14}-$, their past simple occurrences will share a common characteristic: the suffix -ed. Hence, by searching for those tokens with an -ed ending which appear after an inverted comma (" *ed in the concordance tool in WordSmith), reporting verbs can be effectively isolated, as displayed in Figure 1, which shows twenty examples of the 152 hits $^{15}$ retrieved from Jane Eyre:

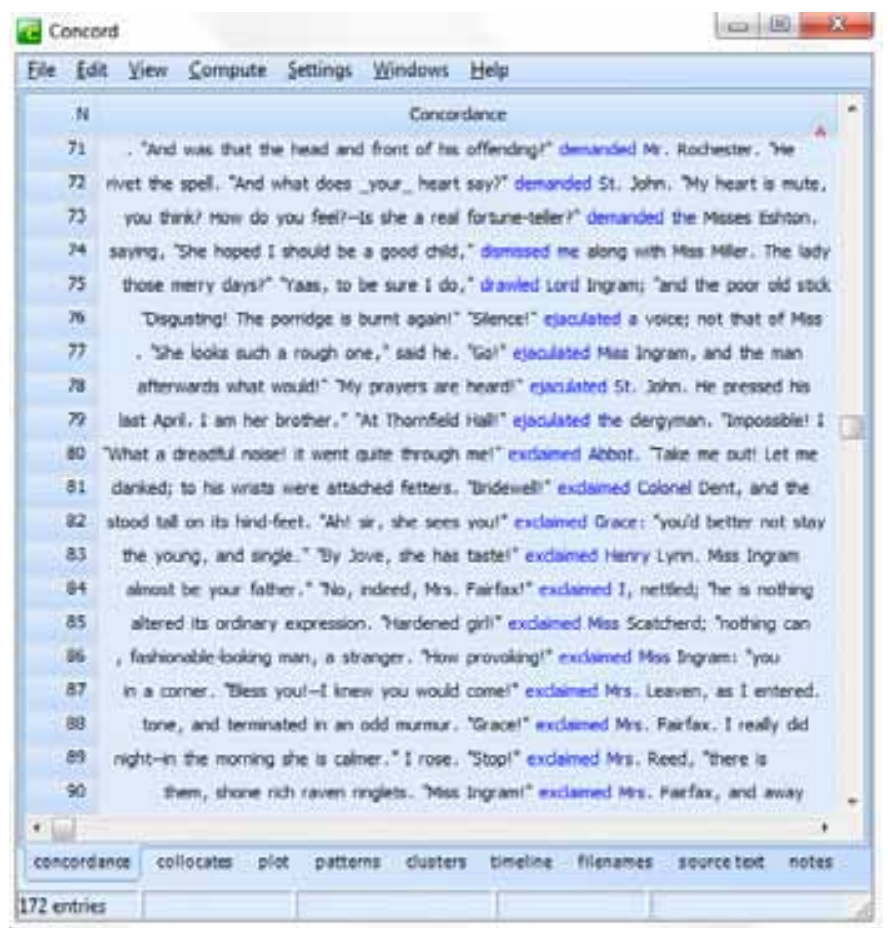

Figure 1. Reporting verbs retrieved in Jane Eyre after concordance " *ed (20 of 152 examples)

Thanks to this concordance, every example like (7) and (8) will be found. It is true, however, that when authors use a personal pronoun instead of the name of the character, the aforementioned pattern is altered, for there is no inversion of the structure subject-verb in the projecting clause:

the narration, for there are cases in which discourse presentation takes place in the present simple tense (half of the chapters in Charles Dickens' Bleak House, for instance).

${ }^{14}$ Importance is here understood as saliency in terms of the information provided about how the speech act is realised. Some examples are told, spoke, went on or began.

${ }^{15}$ Actually, the concordance " *ed retrieves 172 hits, but twenty are not reporting verbs. As it may be expected, there will be instances where, out of pure coincidence, a word with an -ed ending appears after such a sign of punctuation, as in: It was a very grey day; a most opaque sky, "onding on snaw," canopied all; thence flakes felt it intervals, which settled on the hard path and on the hoary lea without melting (my emphasis). Such cases are easy to detect and get rid of. For convenience, the results herein shown will be already polished. 
(9) "You shall walk up the pyramids of Egypt!" he growled. "At your peril you advertise! I wish I had only offered you a sovereign instead of ten pounds. Give me back nine pounds, Jane; I've a use for it."

To overcome this "obstacle", an alternative concordance will suffice (" he *ed). Thus, apart from the search " *ed, three more searches need to be carried out, in order to locate verbs after the third-person singular male pronoun (concordance " he *ed), the third-person singular female pronoun (concordance "she $* e d$ ) and, in the case of novels with a firstperson narrator like Jane Eyre, the first-person singular pronoun (concordance " $I * e d$ ), as in the following examples:

(10) "Gratitude!" he ejaculated; and added wildly-“Jane accept me quickly. Say, Edward-give me my name-Edward-I will marry you."

(11) "We are now without father: we shall soon be without home and brother," she murmured.

(12) “O God! what is it?" I gasped.

\section{Results}

After making these four concordance $\operatorname{searches}^{16}$, a total 31,310 verbs are retrieved in the eighty-four novels under analysis, as shown in Table 1:

Table 1. Reporting verbs retrieved in the Victorian corpus

\begin{tabular}{|l|l|l|l|l|l|}
\hline Author & \multicolumn{1}{|c|}{ Novel } & Verbs & Author & \multicolumn{1}{|c|}{ Novel } & Verbs \\
\hline Brontë & Jane Eyre & 450 & Hardy & Two on a Tower & 241 \\
\hline Brontë & Professor & 457 & Hardy & Under the Greenwood Tree & 118 \\
\hline Brontë & Shirley & 133 & Meredith & Beauchamp's Career & 188 \\
\hline Brontë & Vilette & 306 & Meredith & Evan Harrington & 137 \\
\hline Dickens & Bleak House & 607 & Meredith & Diana of the Crossways & 143 \\
\hline Dickens & Barnaby Rudge & 1163 & Meredith & Farina & 512 \\
\hline Dickens & David Copperfield & 1200 & Meredith & One of Our Conquerors & 62 \\
\hline Dickens & Dombey and Son & 1599 & Meredith & Rhoda Fleming & 296 \\
\hline Dickens & Great Expectations & 475 & Meredith & Sandra Belloni & 507 \\
\hline Dickens & Hard Times & 332 & Meredith & The Adventures of Harry Richmond & 379 \\
\hline Dickens & Little Dorrit & 958 & Meredith & The Amazing Marriage & 68 \\
\hline Dickens & Martin Chuzzlewit & 1835 & Meredith & The Egoist & 198 \\
\hline
\end{tabular}

${ }^{16}$ Because Project Gutenberg texts present irregularities when it comes to the use of inverted commas -texts do not necessarily stick to either simple or double inverted commas consistently-, each of these four concordance searches has had to be made twice. 


\begin{tabular}{|c|c|c|c|c|c|}
\hline Dickens & Nicholas Nickleby & 2479 & Meredith & The Ordeal of Richard Feverel & 398 \\
\hline Dickens & $\begin{array}{l}\text { The Old Curiosity } \\
\text { Shop }\end{array}$ & 990 & Meredith & The Tale of the Chole & 40 \\
\hline Dickens & Our Mutual Friend & 1499 & Meredith & Vittoria & 275 \\
\hline Dickens & Oliver Twist & 1329 & Meredith & The House on the Beach & 57 \\
\hline Dickens & Pickwick Papers & 2255 & Thackeray & Catherine: A Story & 78 \\
\hline Dickens & A Tale of Two Cities & 300 & Thackeray & Men's Wives & 108 \\
\hline Eliot & Adam Bede & 64 & Thackeray & Roundabout Papers & 39 \\
\hline Eliot & Daniel Deronda & 110 & Thackeray & The Book of Snobs & 9 \\
\hline Eliot & Felix Holt, the Radical & 50 & Thackeray & The History of Henry Esmond, Esq. & 93 \\
\hline Eliot & Middlemarch & 158 & Thackeray & The History of Pendennis & 497 \\
\hline Eliot & Romola & 106 & Thackeray & The History of Samuel Titmarsh & 39 \\
\hline Eliot & Silas Marner & 34 & Thackeray & The Luck of Barry Lyndon & 133 \\
\hline Eliot & $\begin{array}{l}\text { The Mill on the } \\
\text { Floss }\end{array}$ & 137 & Thackeray & The Newcomes & 219 \\
\hline Gaskell & Cranford & 48 & Thackeray & The Virginians & 366 \\
\hline Gaskell & Mary Barton & 294 & Thackeray & Vanity Fair & 268 \\
\hline Gaskell & North and South & 250 & Trollope & Can You Forgive Her & 164 \\
\hline Gaskell & Ruth & 257 & Trollope & Doctor Wortle's School & 54 \\
\hline Gaskell & Sylvia's Lovers & 265 & Trollope & He Knew He Was Right & 261 \\
\hline Gaskell & Wives and Daughters & 302 & Trollope & La Vendée & 164 \\
\hline Hardy & A Laodicean & 322 & Trollope & Orley Farm & 197 \\
\hline Hardy & A Pair of Blue Eyes & 307 & Trollope & Phineas Finn & 155 \\
\hline Hardy & Desperate Remedies & 224 & Trollope & Phineas Redux & 130 \\
\hline Hardy & $\begin{array}{l}\text { Far From the Mad- } \\
\text { ding Crowd }\end{array}$ & 252 & Trollope & The Betrams & 155 \\
\hline Hardy & Jude the Obscure & 268 & Trollope & The Duke's Children & 192 \\
\hline Hardy & $\begin{array}{l}\text { Tess of } \\
\text { D'Urbervilles }\end{array}$ & 313 & Trollope & The Eustace Diamonds & 247 \\
\hline Hardy & $\begin{array}{l}\text { The Hand of } \\
\text { Ethelberta }\end{array}$ & 181 & Trollope & The Last Chronicle of Barset & 153 \\
\hline Hardy & $\begin{array}{l}\text { The Mayor of Cast- } \\
\text { erbridge }\end{array}$ & 246 & Trollope & The Prime Minister & 147 \\
\hline Hardy & $\begin{array}{l}\text { The Return of the } \\
\text { Native }\end{array}$ & 237 & Trollope & The Small House at Allington & 159 \\
\hline Hardy & The Trumpet Major & 276 & Trollope & The Way We Live Now & 247 \\
\hline Hardy & The Well-Beloved & 95 & TOTAL & & 31310 \\
\hline Hardy & The Woodlanders & 254 & & & \\
\hline
\end{tabular}


These 31,310 tokens are divided into 269 types, distributed as shown in table 2:

Table 2. Reporting verbs retrieved and occurrences

\begin{tabular}{|c|c|c|c|c|c|c|c|}
\hline Verb & Freq. & Verb & Freq. & Verb & Freq. & Verb & Freq. \\
\hline acquiesced & 8 & demanded & 235 & laughed & 89 & roared & 122 \\
\hline added & 1254 & deplored & 1 & lipped & 1 & ruminated & 2 \\
\hline addressed & 32 & deprecated & 3 & lisped & 7 & rushed & 1 \\
\hline adjured & 1 & dictated & 1 & mimicked & 1 & satirized & 1 \\
\hline admitted & 17 & dismissed & 1 & moaned & 46 & scowled & 1 \\
\hline advanced & 1 & drawled & 19 & moralized & 2 & screamed & 99 \\
\hline affirmed & 12 & droned & 1 & mourned & 4 & screeched & 2 \\
\hline alleged & 5 & echoed & 131 & mumbled & 10 & shouted & 166 \\
\hline allowed & 1 & ejaculated & 122 & murmured & 596 & shrieked & 44 \\
\hline announced & 3 & emphasized & 6 & mused & 33 & shrugged & 1 \\
\hline answered & 1214 & encouraged & 1 & muttered & 276 & sibillated & 1 \\
\hline apologized & 19 & ended & 29 & named & 1 & sighed & 159 \\
\hline apostrophized & 6 & enjoined & 2 & nodded & 12 & simpered & 12 \\
\hline appealed & 6 & enquired & 3 & objected & 3 & slurred & 1 \\
\hline appended & 2 & entreated & 20 & observed & 776 & smiled & 12 \\
\hline argued & 45 & enunciated & 1 & ordered & 3 & snapped & 5 \\
\hline articulated & 1 & exclaimed & 1386 & owned & 3 & snarled & 15 \\
\hline asked & 3469 & excused & 1 & panted & 9 & sneered & 41 \\
\hline assented & 94 & explained & 48 & parried & 1 & sniffed & 2 \\
\hline asserted & 8 & expostulated & 22 & paused & 3 & snored & 1 \\
\hline assured & 8 & expressed & 1 & persevered & 7 & snorted & 2 \\
\hline attested & 3 & faltered & 119 & persisted & 27 & snuffled & 1 \\
\hline averred & 2 & fawned & 1 & persuaded & 1 & sobbed & 106 \\
\hline avowed & 1 & filled & 1 & petitioned & 2 & solicited & 1 \\
\hline bawled & 26 & flamed & 1 & phrased & 1 & soliloquised & 5 \\
\hline beckoned & 2 & flashed & 2 & piped & 6 & sorrowed & 1 \\
\hline begged & 13 & flushed & 1 & pleaded & 131 & speculated & 1 \\
\hline bellowed & 10 & fluted & 1 & pondered & 3 & sprinkled & 1 \\
\hline blared & 1 & fluttered & 1 & pouted & 14 & spurred & 1 \\
\hline bleated & 1 & followed & 2 & prayed & 3 & squeaked & 2 \\
\hline blubbered & 6 & gasped & 74 & preluded & 1 & stammered & 57 \\
\hline blurted & 3 & gibbered & 1 & pressed & 1 & started & 1 \\
\hline blustered & 7 & giggled & 2 & proceeded & 67 & stipulated & 6 \\
\hline
\end{tabular}




\begin{tabular}{|c|c|c|c|c|c|c|c|}
\hline boasted & 1 & glistened & 1 & proclaimed & 4 & stopped & 13 \\
\hline bounced & 4 & grated & 1 & promised & 2 & subjoined & 8 \\
\hline breathed & 26 & grinned & 9 & prompted & 1 & submitted & 5 \\
\hline calculated & 1 & groaned & 67 & pronounced & 14 & suggested & 240 \\
\hline called & 64 & growled & 160 & proposed & 2 & summed & 2 \\
\hline chattered & 1 & grumbled & 21 & protested & 10 & superadded & 1 \\
\hline chimed & 14 & grunted & 3 & pursued & 494 & sympathized & 1 \\
\hline chirped & 2 & gurgled & 2 & quaked & 1 & testified & 1 \\
\hline chirruped & 1 & halloed & 4 & queried & 4 & thanked & 1 \\
\hline choked & 1 & hazarded & 8 & questioned & 10 & threatened & 2 \\
\hline chuckled & 22 & heaved & 1 & quivered & 1 & thumped & 1 \\
\hline coaxed & 14 & hesitated & 13 & quoted & 2 & thundered & 21 \\
\hline commanded & 3 & hiccupped & 4 & rallied & 1 & tittered & 10 \\
\hline commenced & 9 & hinted & 22 & reasoned & 21 & twitted & 1 \\
\hline commented & 5 & hissed & 9 & recollected & 2 & urged & 174 \\
\hline communicated & 2 & howled & 5 & recommenced & 9 & uttered & 17 \\
\hline complained & 6 & hummed & 3 & reflected & 4 & ventured & 2 \\
\hline concluded & 39 & hurried & 2 & rehearsed & 1 & vociferated & 3 \\
\hline confessed & 9 & implored & 35 & reiterated & 27 & volunteered & 1 \\
\hline confided & 4 & importuned & 1 & rejoined & 824 & vowed & 4 \\
\hline confirmed & 1 & indicated & 1 & remarked & 369 & wailed & 8 \\
\hline confronted & 1 & informed & 5 & remembered & 1 & warned & 2 \\
\hline continued & 1637 & inquired & 970 & reminded & 1 & waved & 2 \\
\hline contradicted & 2 & insinuated & 6 & remonstrated & 82 & wheezed & 4 \\
\hline corrected & 2 & insisted & 24 & renewed & 1 & whimpered & 38 \\
\hline corroborated & 3 & insulted & 1 & repeated & 735 & whined & 14 \\
\hline coughed & 6 & interjected & 29 & replied & 4073 & whinnied & 2 \\
\hline counselled & 3 & interposed & 371 & reproached & 1 & whispered & 508 \\
\hline counted & 1 & interpreted & 1 & requested & 1 & whistled & 4 \\
\hline cried & 4114 & interrupted & 181 & resolved & 2 & wondered & 1 \\
\hline croaked & 26 & iterated & 2 & responded & 101 & yawned & 5 \\
\hline crowed & 2 & jeered & 1 & resumed & 324 & yelled & 3 \\
\hline darted & 1 & jerked & 4 & retorted & 449 & TOTAL & 31310 \\
\hline dashed & 1 & joined & 2 & returned & 3080 & & \\
\hline declared & 24 & languished & 1 & rhymed & 1 & & \\
\hline
\end{tabular}


Such an unprecedented amount of data reinforces, beyond the case study detailed in the next section, the applicability of corpus approaches to studies in teaching and learning. Indeed, the body of evidence under analysis here presents not only a vast catalogue of reporting verbs available to anyone interested in the field but, having been carried out over more than eighty different texts, it proves true the replicability of the methodological procedure as well, which may be applied to any other set of texts, either literary or non-literary.

Results, though, should be taken with a pinch of salt, for some of the verbs are certainly on the wane after more than a century since they were originally used. This is the case of ejaculated ${ }^{17}$, "an example of a change of meaning in the 20th century" (Busse 2010: 246). Currently used mostly to refer to body fluids, in the nineteenth century it was an idiosyncratic verb to express sudden exclamations ${ }^{18}$, as the 122 examples retrieved demonstrate. However, apart from these examples, which should be easy to spot and get rid of, most of the verbs which shape the catalogue make it possible to pinpoint different stances towards the words being reported and thus demonstrate that there exist implications in the use of certain reporting verbs. Such implications may be highlighted when teaching discourse presentation strategies, since they play a fundamental role in terms of faithfulness oftentimes disregarded. Let us have a look at some examples which will ratify their importance and their need to be tackled in teaching contexts.

\section{A case Study}

Coming back to Charles Dickens' A Tale of Two Cities, commented on at the beginning, a total of 300 hits are retrieved. Such examples amount to forty-three verbs, distributed as in table 3 :

Table 3. Reporting verbs in Charles Dickens' A Tale of Two Cities

\begin{tabular}{|c|c|c|c|c|c|c|c|}
\hline Verb & Freq. & Verb & Freq. & Verb & Freq. & Verb & Freq. \\
\hline added & 5 & ejaculated & 1 & murmured & 2 & remonstrated & 1 \\
\hline answered & 23 & exclaimed & 12 & muttered & 9 & repeated & 21 \\
\hline argued & 1 & explained & 1 & observed & 12 & replied & 4 \\
\hline asked & 35 & growled & 4 & paused & 1 & resumed & 2 \\
\hline assented & 5 & grumbled & 1 & pleaded & 1 & retorted & 3 \\
\hline bawled & 1 & hinted & 1 & proceeded & 2 & returned & 54 \\
\hline called & 1 & implored & 1 & protested & 1 & shrieked & 1 \\
\hline cried & 40 & inquired & 5 & pursued & 14 & suggested & 1 \\
\hline croaked & 8 & interrupted & 1 & reasoned & 1 & urged & 3 \\
\hline demanded & 6 & laughed & 2 & rejoined & 5 & whispered & 3 \\
\hline echoed & 2 & mourned & 1 & remarked & 2 & TOTAL & 300 \\
\hline
\end{tabular}

${ }^{17}$ See example (10).

${ }^{18}$ This is its definition as a reporting verb, according to the OED: 2. To utter suddenly (a short prayer; now in wider sense, any brief expression of emotion). 
This catalogue ranges from structuring neutral verbs (added, replied or returned) to very specific choices (bawled, croaked or growled), which may affect the way in which the words glossed are perceived. If the above-detailed concordance searches are made with Penguin Reader's Charles Dickens' A Tale of Two Cities (upper-intermediate level) ${ }^{19}$, though, only 101 hits are retrieved, divided into fifteen mostly regular and structuring verbs:

Table 4. Reporting verbs in the simplified version of A Tale of Two Cities

\begin{tabular}{|c|c|c|c|c|c|c|c|}
\hline Verb & Freq. & Verb & Freq. & Verb & Freq. & Verb & Freq. \\
\hline answered & 13 & continued & 2 & paused & 1 & suggested & 1 \\
\hline asked & 22 & cried & 24 & remarked & 2 & shouted & 2 \\
\hline begged & 2 & inquired & 1 & repeated & 6 & whispered & 4 \\
\hline called & 1 & laughed & 1 & replied & 19 & TOTAL & 101 \\
\hline
\end{tabular}

So let us take both texts as a case in point to illustrate the importance of dealing with direct speech when teaching discourse presentation strategies. To begin with, not only a much less verbs -quantitatively speaking- are retrieved, but there is no trace of such verbs as bawled, croaked, demanded, exclaimed, growled, grumbled, implored, mourned, murmured, muttered, pleaded, protested, remonstrated or shrieked. This unevenness results in a paucity of details that, in the original novel, do contribute to the projection of character traits by showing their attitudes to the words they utter. Due to length constraints, I will only focus on one example: croaked. This single instance however, will ratify how verbs may play a role that goes well beyond the linguistic function the play by their very nature. A look at the eight examples retrieved reveals that, in fact, six of them are attached to a single character, Jacques Three:

(13) "Kill him!" croaked Jacques Three, who had come close up.

(14) “A. M.!" croaked Jacques Three, as he read greedily.

(15) “Magnificent!” croaked Jacques Three. The Vengeance, also, highly approved.

(16) "It is a great pity," croaked Jacques Three, dubiously shaking his head, with his cruel fingers at his hungry mouth; "it is not quite like a good citizen; it is a thing to regret."

(17) "She has a fine head for it," croaked Jacques Three. "I have seen blue eyes and golden hair there, and they looked charming when Samson held them up." Ogre that he was, he spoke like an epicure.

(18) "That must never be," croaked Jacques Three; "no one must escape. We have not half enough as it is. We ought to have six score a day."

Jacques is the name by which five of the French revolutionaries are known in Dickens' twelfth novel. This code name is used so that they do not know each other's actual identi-

${ }^{19}$ In order to be processed with the software, the text had to be converted into a plain text file. To do so, I scanned the text and processed it with an OCR (Optical Character Recognition) software, the norm for digitised texts. Needless to say, typos are likely to occur, but this is a sword of Damocles even hanging over Project Gutenberg texts, site par excellence for digitised texts. 
ties. Thus, they would not be able to give away their fellows in case they are captured. In the particular case of Jacques Three, he is described as a bloodthirsty rascal ${ }^{20}$. Thus, taking these six examples into consideration, it can hardly be denied that Dickens' choices are far from serendipitous, especially if we bear in mind that they account for more than half of Jacques Three's overall textual life ${ }^{21}$. By resorting to both direct speech and such a reporting verb, Dickens -through the figure of the narrator- not only introduces the revolutionary's words as they were supposedly uttered, but he also takes a stand towards his character. We, as readers, perceive him as a mean person. And we do so precisely because of that specific choice, since this would have been impossible if Dickens had used read, said or remarked to introduce such speech acts, as it occurs in the simplified version ${ }^{22}$ :

(19) 'A.M.', read Jacques.

(20) 'It is a great pity,' said Jacques Three. 'A good Republican should not be sorry for such people.'

(21) 'She had a fine head for the guillotine,' remarked Jacques Three. 'I have seen blue eyes and fair hair there, and they looked beautiful when held up and shown to the people.'

(22) 'That must never be', said Jacques Three. 'No one must escape. We have not enough heads as it is. We ought to have at least a hundred a day.'

Whether and to what extent this lack of specificity -exemplified through croaked but generalisable to the rest of the verbs- poses a flaw in the simplified version is open to debate, of course. Some people may argue that this is just a graded reading, whilst some others will surely find it faulty being upper-intermediate reading material. In either case, what cannot be denied is that when such a highly interpretive element is systematically neglected, a far from innocent nuance is lost. Without questioning the Spanish curriculum on the basis of just an example, it is an undisputable fact, though, that reporting verbs play a decisive role when shaping how reported discourse is understood.

This still embryonic formulation, of course, needs further study to be considered as a feasible option for teaching discourse presentation strategies. It would certainly be interesting to analyse the pragmatic function of reporting verbs on a larger scale than this study permits. This would shed further light on the implications that biased choices may entail. The study of different genres, for instance, would reinforce the facts herein discussed through real life examples (the skewed language of newspapers comes quickly to mind, for obvious reasons). Due to length constraints, however, here I just aimed to point out a detected flaw in EFL teaching, bolstering it with tangible data from Victorian fiction. In doing so, I have tried to come up with a sensible proposal, which offers both a catalogue of verbs available to anybody interested in them and a replicable methodological procedure. Now it must be decided whether this proposal deserves further attention within teaching and learning con-

\footnotetext{
${ }^{20}$ It may be worth recalling that he is a member of the rotten tribunal that sentences Charles Darnay to execution.

${ }^{21}$ Indeed, there are only ten examples attached to this character. For an in-depth analysis of Jacques Three through the use of reporting verbs, see Ruano San Segundo (forthcoming).

${ }^{22}$ With examples (13) and (15) no comparison can be made, since they are part of the deletions made to shorten the original version.
} 
texts. On the basis of the examples herein shown, however, it does not seem unreasonable to use some of them to explain (i) different realisations of direct speech through different and varied reporting verbs and (ii) how these realisations are not mere stylistic variation. Besides, doing it with nineteenth-century English fiction would help to integrate literature in the learning process.

\section{Concluding remarks}

Direct speech, as well as other discourse presentation strategies, has traditionally lacked the attention devoted to indirect speech in EFL teaching in the Spanish curriculum. Whatever the reason, the truth is that students do not systematically deal with the discourse presentation par excellence, which results in a gap in their learning at different stages. This neglect does not take into account the implications that direct speech may entail. On the contrary, the verbatim representation of the speech act being reported seems as a takenfor-granted construction which does not need further analysis. Thanks to a corpus-based approach, though, it is possible to retrieve thousands of examples that prove otherwise. By analysing reporting verbs, it is possible to demonstrate that the way in which discourse is projected can be interpretative and highly intrusive. In the case of this particular research, nineteenth-century English fiction has proven to be a rich source of examples, which can furthermore help to integrate literature in the curriculum, a still unresolved matter in EFL teaching in Spain.

\section{Bibliography}

Biber, D. (2011). "Corpus linguistics and the scientific study of literature: Back to the future?". in Scientific Study of Literature, 1, 1: 15-23.

Biber, D., Conrad, S. and Reppen, D. (1998). Corpus Linguistics: Investigating Language Structure and Use. Cambridge: Cambridge University Press.

Brüngel-Dittrich, M. (2006). Speech Presentation in British and German Press. New York: Peter Lang.

Busse, B. (2010). Speech, Writing and Thought Presentation in a Corpus of Nineteenth-Century English Narrative Fiction. Bern: University of Bern.

Caldas-Coulthard, C.R. (1987). "Reported speech in written narrative texts", in R. M. Coulthard (ed.), Discussing Discourse. Birmingham: University of Birmingham, 149-167.

Caldas-Coulthard, C.R. (1988). Reporting Interaction in Narrative: A Study of Speech Presentation in Written Discourse. Unpublished Ph. D Thesis. University of Birmingham.

Dickens. Charles (2000). A Tale of Two Cities. Retold by A. Johnson and G. C. Thornely. Level 5. London: Penguin Books.

Halliday, M. A. K. 2004. An Introduction to Functional Grammar, $3^{\text {rd }}$ edition (revised by C. M. I. M. Matthiessen). London: Arnold.

Lambert, Mark (1981). Dickens and the Suspended Quotation. New Haven: Yale University Press. Leech, G and Short, M. (2007 [1981]). Style in Fiction. London: Longman.

Mahlberg, M. (2013). Corpus Stylistics and Dickens's Fiction. London: Routledge. 
Ruano San Segundo, Pablo (forthcoming). “A Corpus-Based Approach to Dickens' Use of Speech Verbs: Beyond Mere Reporting”, in International Journal of Corpus Linguistics.

Scott, M. (2013). WordSmith Tools. Version 6. Liverpool: Lexical Analysis Software.

Semino, E. and Short, M. (2004). Corpus Stylistics. Speech, Thought and Writing Presentation in a Corpus of English Writing. London. Routledge.

Sinclair, J. (2004). Trust the Text. Language, Corpus and Discourse. London: Routledge.

Taylor Torsello, C. (2007). "Projection in literary and non-literary texts", in D. R. Miller and M. Turci (eds.), Language and Verbal Art Revisited. London: Equinox, 115-48.

Wierzbicka, A. (1987). English Speech Act Verbs: A Semantic Dictionary. Sydney: Academic Press. http://www.boe.es/boe/dias/2015/01/03/pdfs/BOE-A-2015-37.pdf ; accessed February 24, 2015 
